\title{
Görme Yetersizliği Olan Öğrencilerin Derslerini Yürüten Akademisyenlerin Karşılaştıkları Güçlüklerin Belirlenmesi
}

\author{
DOI: $10.26466 /$ opus. 916007
}

\author{
* \\ Gülistan Yalçın* - Cem Aslan** \\ * Dr., Aksaray Üniversitesi, Eğitim Fakültesi, Aksaray/Türkiye \\ E-Posta: gulistanyalcin@aksaray.edu.tr \\ ORCID: $\underline{0000-0002-9668-0359}$ \\ ** Dr., Gazi Üniversitesi, Eğitim Fakülte, Ankara/Türkiye \\ E-Posta: cemaslan@gazi.edu.tr \\ ORCID: $\underline{0000-0002-0300-5873}$
}

\section{Öz}

$B u$ çalışmada, görme yetersizliği olan öğrencilerin derslerini yürüten akademisyenlerin karşılaştıkları güçlüklerin belirlenmesi amaçlanmıştır. Betimsel araştırma modeline göre yürütülen çalışmanin katıllmcıları, görme yetersizliği olan üniversite öğrencilerinin bulunduğu sinıflarda derslere giren 115 akademisyen oluşturmaktadır. Katılımcıların 67'si (\%58.2) kadın, 48'i (\%41.7) erkektir ve katılımcılar üniversitelerin farklı bölümlerinde görev yapmaktadır. Çalışmanın veri toplama süreci, elektronik ortamda gerçekleştirilmiştir. Veriler araştırmacılar tarafından oluşturulan anket aracıliğıyla toplanmış, frekans ve yüzde alma teknikleri kullanılarak analiz edilmiştir. Sonuç olarak, çalışmaya katılan akademisyenlerin en fazla kitap, makale gibi kaynak materyalleri verme konusunda güçlük yaşadıkları belirlenmiştir. Ayrıca katıllmcıların, görsel içerikli dersleri anlatma, stnav soruların hazırlama veya uygun hale getirme, üniversitenin sağladığı imkânlara ulaşma, ödev verme, sınavları yapma, ders araçlarım uyarlama konularında güçlüklerle karşılaştıkları tespit edilmiştir. Ek olarak katılımcıların, bağımsız hareket etmeyi destekleme, farklı mekanlarda ders yapma, ek süre verme, sinav evraklarını okuma, sözlü ders anlatma, ders içeriğini ve işleyişini anlatma konularında ise daha az güçlük yaşadıkları belirlenmiştir. Bu çalışmadan elde edilen akademisyen görüşleri, ilgili araştırmalar doğrultusunda tartışılmış ve ileride yapılacak araştırmalara ve uygulamalara yönelik önerilere yer verilmiştir.

Anahtar Kelimeler: Görme yetersizliği olan öğrenciler, görme yetersizliği olan öğrencilerle çalışan akademisyenler, eğitimde yaşanan güçlükler. 


\title{
Determining the Difficulties Encountered by Academicians Teaching with Students with Visual Impairments
}

\begin{abstract}
This study aimed to determine the difficulties encountered by academicians teaching with students with visual impairments. The study participants, which was designed according to the descriptive research model, consisted of 115 academicians who attended classes in classes with students with visual impairments. 67 (58.2\%) of the participants are female, $48(41.7 \%)$ are male, and the participants work in different departments of the universities. The data collection process of the research was carried out electronically. The data were collected through a questionnaire created by the researchers and analyzed using frequency and percentage techniques. As a result, it was determined that the academicians participating in the study had the most difficulty giving source materials such as books and articles. In addition, it was observed that they faced challenges in lecturing with visual content, preparing or adaptation questions, accessing the opportunities provided by the university, assignments, exams, and adapting the course materials. However, it was determined that they had less difficulty supporting the independent movement, teaching in different places, giving additional time, reading exam documents, giving oral lessons, explaining the course content and procedure. Academicians' opinions were discussed in line with the relevant literature, and suggestions were provided for further studies and applications.
\end{abstract}

Key Words: Students with visual impairments, academicians working with students with visual impairments, educational difficulties. 


\section{Giriş}

Görme yetersizliği, ülkemizde Özel Eğitim Hizmetleri Yönetmeliği'ne göre "görme engelli birey" olarak ifade edilmekte ve "Görme gücünün kısmen ya da tamamen kaybından dolayı özel eğitim ve destek eğitim hizmetine ihtiyacı olan birey" olarak tanımlanmaktadır (Özel Eğitim Hizmetleri Yönetmeliği (ÖEHY), 2018). Tanıma göre, görme yetersizliğinin hem kısmen görmesi olan (az gören) hem de hiç görmeyen (total görme yetersizliği) bireyleri kapsadığı söylenebilir. Nitekim, görme yetersizliğinin bu iki grupta yer alan bireyleri içeren şemsiye bir terim olduğu ifade edilmektedir (Kreuzer, 2007). Bireyde görme yetersizliğinin varlığı, özellikle görme ile ilgili becerilerin veya görevlerin gerçekleştirilmesini güçleştirebilir. Bu durum günlük yaşamda karşılaşılabileceği gibi akademik ortamlarda da kendini gösterebilir. Az gören bireyler, akademik ve günlük yaşamlarında arta kalan görmelerini kullanabilirken; total görme yetersizliği olan bireyler ise söz konusu bu güçlüklerin üstesinden gelebilmek için diğer duyularını kullanırlar. Bu bağlamda, özellikle eğitim-öğretim faaliyetlerine katılabilmeleri için görsel materyallerle birlikte dokunsal ve işitsel içerikli materyallere de gereksinim duyarlar (Yalçın ve Kamalı Arslantaş, 2020).

Görme yetersizliği olan bireylere hizmet veren önemli yerlerden biri hiç kuşkusuz okullardır. Görme yetersizliği olan bireylerin öğrenim gördükleri eğitim ortamları çeşitlilik göstermektedir. Örneğin, ilköğretim kademesinde çoğunlukla görme engelliler okullarında eğitim almakla birlikte, özel sınıf veya kaynaştırma sınıflarında da eğitim-öğretimlerine devam edebilmektedirler. Bu bireyler, özellikle görme engelliler okullarındaki eğitimleri sürecinde öğretim materyallerinin pek çoğunu dokunma ve/veya işitme gibi öğrenme kanallarına hitap edecek şekilde almaktadırlar. Örneğin braille formatta hazırlanmış ders materyalleri, bağımsız hareket etmelerini destekleyecek bina içi düzenlemeler bunlardan bazılarıdır. Ortaöğretim ve/veya yükseköğretime geldiklerinde ise bireysel yetersizliklerine uygun olarak açılmış ayrı okullardan ziyade gören öğrencilerle aynı eğitim ortamlarına devam ederler. Buradaki öğrenim süreçlerinde ise özel hazırlanmış ya da düzenlenmiş materyallere erişimleri oldukça sınırlı olmaktadır. Oysaki görme yetersizliği olan bireylerin eğitimlerine devam edebilmeleri için özel olarak tasarlanmış 
araçların ve uyarlanan öğretim yöntemlerinin kullanılması gerekebilmektedir (Kamış ve Demir, 2018). Dolayısı ile görme yetersizliği olan bireylerin çeşitli zorluklarla karşılaşabileceklerini söylemek yanlış olmayacaktır. Nitekim lise öğrencileri ile yapılan bir çalışmada; öğretmenlerin, görme yetersizliği olan öğrenciler için dersler, ödev hazırlama, sınavlara hazırlanma ve sınavlar sırasında sınırlı şekilde düzenlemelere yer verdiği belirlenmiştir (Yalçın, 2015). Bu durum görme yetersizliği olan bireylerin gören akranları ile eşit eğitim almaların engelleyen bir faktör olarak görülebilir. Diğer bir ifadeyle görme yetersizliği olan bireylerin eğitim imkânlarından eşit bir biçimde yararlanamadıkları ve eğitim-öğretim içeriklerine erişim sınırlılığı yaşadıkları sonuçlarına gidilebilir.

Görme yetersizliği olan bireylerin eğitiminde erişilebilirlik, bu bireylerin gören akranları ile aynı eğitim yaşantılarını elde etmesi açısından önem arz etmektedir. Eğitimde erişilebilirlik denildiğinde bunlar; a) Okul binalarına erişim, b) Derslere erişim, c) Kaynak kitap, dergi gibi materyallere erişim ve d) Sınavlara erişim olmak üzere dört başlık altında incelenebilir. a) Okul binalarına erişim, görme yetersizliği olan bireyler için sınıfın ve/veya okulun her bölgesinde birtakım uyarlamaların yapılması ile sağlanabilir (Tuncer, 2014). Örneğin, az gören öğrenciler için merdiven basamaklarının zit renklere boyanması, kız/erkek tuvaletlerinin braille yazılarla veya simgelerle belirtilmesi, yemekhanenin aynı şekilde ayırt ediciliğini sağlayacak nesneler ya da yazılarla belirtilmesi, sınıf içindeki eşyaların sık sık yerlerinin değiştirilmemesi gibi küçük düzenlemelerle görme yetersizliği olan bireyler için okul binalarına erişim sağlanabilir. $b$ ) Derslere erişim, görme yetersizliği olan bireyler için ders işlenişi sırasında çeşitli öğretimsel düzenlemeler yapılarak dersin daha etkili ve verimli hala getirilmesini ifade etmektedir. Öğretmenler, ders sırasında tahtaya yazdığı ya da çizdiği nesneyi aynı zamanda betimleyerek görme yetersizliği olan bireyin de derse erişimini sağlayabilir ya da derste Power Point sunusuna yer veriyorsa içeriği büyük puntoda yazıp yansıtabilir ya da az gören öğrenciye yardımcı teknolojik araçlar (ör. teleskopik gözlük) temin edilebilir. Bu tür basit düzenlemelerle görme yetersizliği olan bireylerin de gören akranları gibi verilen bilgi ve becerileri edinmeleri sağlanabilir. c) Kaynak kitap, dergi gibi materyallere erişim, görme yetersizliği olan bireylerin ihtiyaçlarına uygun ders materyallerinin sağlanmasını ifade et- 
mektedir (Tuncer, 2014). Örneğin braille okuyucular için braille kitap, makale ve dergi, az gören öğrenciler için büyük puntolu ders kitabı ya da basılı metinleri okumaya yarayan ekran okuma programları, gören yazıyı büyütmeye yarayan el büyüteçleri bunlardan bazılarıdır. d) Stnavlara erişim, görme yetersizliği olan bireylerin ihtiyaçlarına yönelik sınav materyallerinin düzenlenmesini ifade eder. Bu düzenlemeler; bireyin görme durumuna göre braille ya da büyük puntolu sınav kağıdının sunulması, gören okuyucu tarafından soruların okunarak cevaplarının yazımı, sınavda ek süre verilmesi ve sınavın ses kayıt cihazıyla gerçekleştirilmesi gibi farklı uygulamaları içerir (Allman, 2009; Bolt and Thurlow, 2004; Doğuş, Aslan ve Çakmak, 2020; Douglas, McCall, Pavey and Nisbet, 2009; Kim, 2012; Smith and Amato, 2012; Stone, Cook, Laitusis and Cline, 2010).

Uluslararası sözleşmelerde, yetersizliği olan bireylerin birçok hizmete veya içeriğe erişimlerinin sağlanması için gerekli tedbirlerin alınması gerektiği vurgulanmaktadır. Örneğin Birleşmiş Milletler Engelli Hakları Sözleşmesi'nin 9. maddesinde yetersizliği olan bireylerin toplumun tüm alanlarına (okul, işyeri, sağlık tesisleri, ulaşım araçları vb.) tam katılımının sağlanması ve bu bireylerin olağan gelişim gösteren bireyler gibi çevreye, ulaşıma, bilgi ve erişim teknolojisi ve sistemi dâhil olmak üzere bilgi ve iletişime, halka açık olan her yerde sunulan hizmetlere erişiminin sağlanması için gerekli tedbirlerin alınması gerektiği belirtilmiştir. Yine aynı maddenin devamında yetersizliği olan bireylerin karşılaştığ 1 erişim sorunlarına yönelik eğitilmelerine de yer verilmiştir. Bununla birlikte ülkemizde ise 5378 sayılı Engelliler Hakkında Kanun gereğince, Yükseköğretim Kurulu (YÖK) tarafından hazırlanan "Yükseköğretim Kurumları Engelliler Danışma ve Koordinasyon Yönetmeliği" (2006) yayımlanmıştır. Buna göre yetersizliği olan bireylerin öğrenim hayatlarını kolaylaştırabilmek için gerekli tedbirlerin alınmasının ve bu yönde düzenlemelerin yapılmasının önü açılmıştır. Ek olarak yetersizliği olan bireylerin yükseköğretim ortamlarına, materyallere ve derslere erişimini sağlama konusunda YÖK'ün pek çok tedbir aldığı ve bu bireylerin erişimini destekleme noktasında üniversiteleri motive edecek bazı ödüller (ör. engelsiz bayrak ödülleri) verdiği bilinmektedir. Öte yandan üniversitelerde öğrenim gören yetersizliği olan bireylerin öğrenim hayatlarını kolaylaştırmak için gerekli tedbirleri almak ve bu yönde çalışmalar yapmak üzere Engelli Öğrenci Birimleri (rastlanılan diğer adıyla Engelsizler 
Birimi) kurulmuştur. Genel uygulamalar haricinde üniversiteler özelinde yapılan uygulamalara da rastlanılmaktadır. Pek çok üniversitede faaliyet gösteren engelli öğrenci birimleri, yetersizliği olan bireylerin derslere ve sınavlara erişimini desteklemek amacıyla çeşitli uygulamalar yapmaktadırlar. Örneğin bazı üniversitelerde yetersizliği olan öğrenciler için eğitim-öğretim ve sınav uygulama yönergelerinin hazırlandığ bilinmektedir. $\mathrm{Bu}$ yönergeler incelendiğinde öğrencilerin derslere ve sınavlara bağımsız bir şekilde erişimini destekleyecek uygulamaların yer aldığ1 görülmektedir. Ancak bu yönergelerde yer alan uygulamaların öğretim elemanları tarafından hangi düzeyde gerçekleştirildiğine ilişkin bilgiler bulunmamaktadır.

Alanyazında görme yetersizliği olan öğrencileri bulunan öğretim elemanlarının/öğretmenlerin karşılaştıkları güçlükleri belirlemeye yönelik sınırlı sayıda araştırmaya rastlanılmıştır. Örneğin bu araştırmalardan birinde görme yetersizliği olan öğrencilerin sınavlarda yardım istemesi, ders sırasında görme yetersizliği olan öğrencinin unutulması ve sorulardan değişiklik yapılması öğretim elemanları tarafından bir sorun olarak dile getirilmiştir (Kamış ve Demir, 2018). Diğer araştırmalarda ise öğretmenlerin yeterli donanıma sahip olmaması, görme yetersizliği olan bireylerin öğrenmeleri hakkında bilgi sahibi olunmaması gibi konularda güçlükler öne sürülmüştür (Şendurur, 2016; Uğurlu ve Çobanoğlu-Aktan, 2016). Ancak bu araştırmalar istatistik öğretimi (Uğurlu ve ÇobanoğluAktan, 2016), çalg1 öğretimi (Şendurur, 2016) ve ölçme-değerlendirme süreci (Kamış ve Demir, 2018) gibi belirli bir alan veya konu bağlamında gerçekleştirilmiştir. Bu anlamda ulaşılan sonuçların önemli bir bakış açısı sağladığı söylenmekle birlikte, bulguların genellenmesi konusunda sınırlı kaldığı söylenebilir. Çoğu akademisyen çalışma yaşamları boyunca yetersizliği olan birey ile sınırlı sayıda karşılaşmakta ya da hiç karşılaşmamaktadır. Bu nedenle söz konusu bireylerin ihtiyaçlarının ne olduğu konusunda sınırlı bilgiye sahip olmakta ve hangi düzenlemeleri nasıl yapacakları konusunda desteğe ihtiyaç duyabilmektedir. Bu yönüyle, öğretim elemanlarının görme yetersizliği olan bireylerle çalışırken, diğer ifadeyle derslerini yürütürken çeşitli sorunlar yaşayabilecekleri düşünülmektedir. Bu bireylerle çalışacak eğitimcilere ders öncesi, sırası veya sonrasında birçok görev düşmektedir (Güray, 2017). Görme yetersizliği olan bireylerle çalışan öğretim elemanlarının yaşadıkları sorunların 
tespit edilmesi ve söz konusu sorunlara çözüm önerilerinin getirilmesi için bu çalışma önemli zemin oluşturacaktır. Dolayısıyla yapılan bu çalışmanın önemli olduğu düşünülmekle birlikte alanyazındaki bilgi birimine katkı sağlaması beklenmektedir. Ayrıca görme yetersizliği olan bireylere sunulan hizmetlerin iyileştirilmesi için var olan durumun betimlenmesi de önemli görülmektedir. Bu kapsamda, çalışmada görme yetersizliği olan bireylerin eğitime erişilebilirliğini sağlamada en büyük paydaşlardan olan akademisyenlerin karşılaştıkları güçlüklerin belirlenmesi amaçlanmıştır.

\section{Yöntem}

Görme yetersizliği olan üniversite öğrencilerinin eğitime erişilebilirliğini sağlamada en büyük paydaşlardan olan akademisyenlerin karşılaştıkları güçlükleri belirlemeyi amaçlayan bu çalışma, betimsel araştırma modeline göre desenlenmiştir. Betimsel araştırmalar, "Belli bir zaman kesiti içinde çok sayıda denek veya objeden elde edilen verilerin analizi ile araştırma problemlerine cevap arandığında uygulanacak araştırma yöntemi"dir (Arseven, 1994, s.92).

\section{Katılımcilar}

Bu çalışmanın katılımcılarını, görme yetersizliği olan üniversite öğrencilerinin bulunduğu siniflarda derslere giren 115 akademik personel oluşturmaktadır. Katılımcılara cinsiyet ve görev yaptıkları bölümlere ilişkin bilgiler aşağıdaki tabloda yer almaktadır.

Tablo 1. Katılımcılara ilişkin bilgiler

\begin{tabular}{lcc}
\hline Cinsiyet & $\mathbf{N}$ & $\mathbf{\%}$ \\
\hline Kadın & 67 & 58.2 \\
Erkek & 48 & 41.7 \\
\hline Bölüm & $\mathbf{N}$ & $\mathbf{\%}$ \\
Özel Eğitim Öğretmenliği & 30 & 26.0 \\
Müzik Öğretmenliği & 20 & 17.3 \\
Tarih Öğretmenliği & 18 & 15.6 \\
Fen Bilimleri Öğretmenliği & 16 & 13.9 \\
Okul Öncesi Öğretmenliği & 13 & 11.3 \\
İktisat ve İşletme & 10 & 8.6 \\
Eğitimde Ölçme ve Değerlendirme & 8 & 6.9 \\
\hline
\end{tabular}


Tablo 1'de görüldügüü üzere katılımcıların 67'si (\%58.2) kadın, 48'i (\%41.7) erkektir. Bununla birlikte katılımcıların 30'u (\%26.0) özel eğitim öğretmenliği, 20'si (17.3) müzik öğretmenliği, 18'i (\%15.6) tarih öğretmenliği, 16'sı (\%13.9) fen bilimleri öğretmenliği, 13'ü (\%11.3) okul öncesi öğretmenliği, 10'u (\%8.6) iktisat ve işletme ve 8'i (\%6.9) eğitimde ölçme ve değerlendirme bölümünde görev yapmaktadır.

\section{Veri Toplama Aracı}

Akademisyenlerin karşılaştıkları güçlükleri belirlemek amacıyla araştırmacılar tarafından bir anket geliştirilmiştir. İki bölümden oluşan anketin ilk bölümünde kişisel bilgiler (cinsiyet, bölüm), ikinci bölümünde ise 17 kapalı uçlu soru ve soruların yanıtlarını işaretlemek için "Evet" ve "Hayır" kutucukları bulunmaktadır. Aşağıda veri toplama aracının geliştirilme sürecine yer verilmiştir.

Araştırmacılar, çalışmanın amacı kapsamında alan yazın taraması yapmış ve madde havuzu oluşturmuşlardır. 35 sorudan oluşan madde havuzu, araştırmacılar tarafından incelenmiş ve ankette kullanılmak üzere 20 madde belirlenmiştir. Her madde için "Evet" ve "Hayır" kutucukları hazırlanarak ölçme değerlendirme alanında bir uzman ile birlikte görme engellilerin eğitimi alanında iki uzmandan görüş alınmıştır. Uzman görüşleri araştırmanın birinci yazarı tarafından birebir görüşmeler yapılarak gerçekleştirilmiştir. Araştırmacı, ilk olarak çalışmanın amacı hakkında bilgi vermiş, ardından uzmanlardan, maddelerin çalışmanın amacına hizmet etme, kapsam geçerliği ve anlaşılırlığı olmak üzere üç farklı durum için incelemesini istemiştir. Uzmanlar ilk olarak anketi genel olarak incelemiş ardından her bir madde üzerinde tek tek durarak maddelere ilişkin görüşlerini bildirmişlerdir. Araştırmacı, uzmanların her bir maddeye ilişkin uygun bulup bulmama durumunu kaydetmiştir. Uzmanlardan gelen öneriler doğrultusunda 3 madde diğer maddelerin bazıları ile benzerlik gösterdiğinden çıkarılmış, 4 madde ise yeterince anlaşılır olmadığından yeniden düzenlenmiş ve 17 maddeden oluşan ankete son hali verilmiştir. 


\section{Verilerin Toplanması}

Çalışmanın veri toplama süreci, elektronik ortamda gerçekleştirilmiştir. Araştırmacılar, üniversitelerin Engelli Öğrenci Birim Koordinatörleri'ne email aracılı̆̆g ile ulaşarak üniversitelerin hangi bölümlerinde görme yetersizliği olan öğrenci olduğu bilgisini almış ve o bölümlerde görev yapan akademik personellerin kurum e-mail adreslerine anketi göndermişlerdir. Bu kapsamda anket toplam 178 akademisyene gönderilmiş, bunlardan 115 'i anketi doldurarak tekrar araştırmacılara göndermiştir. Diğer akademisyenler ise anketle ilgili herhangi bir geri dönüş yapmamıştır. Elde edilen anket sayısı araştırmacılar tarafından yeterli görülmüş ve veri analiz sürecine geçilmiştir.

\section{Verilerin Analizi}

Çalışmanın verileri frekans ve yüzde alma teknikleri kullanılarak analiz edilmiştir. Bu kapsamda ankette yer alan maddelere ilişkin tablo oluşturulmuş ve yanıtların (evet, hayır) frekans ve yüzdeleri verilmiştir.

\section{Bulgular}

$\mathrm{Bu}$ bölümde, çalışmanın bulgularına yer verilmiştir. Tablo 2'de ankette yer alan maddelere ait frekans ve yüzdelik değerlere yer verilmiştir.

Tablo 2 incelendiğinde katılımcıların en çok, ders izlencesini görme yetersizliği olan öğrenci için düzenlemede (\%75.6), görsel içeriğin (matematik, fen, sosyal bilimlerle ilgili dersler) yoğun olduğu dersleri anlatmada (\%87.8), akıllı tahta kullanılması gerektiğinde (\%77.3), Power Point sunumu, videolar, beher, cetvel gibi ders materyallerini görme yetersizliği olan öğrenci için uyarlamak/düzenlemek gerektiğinde (\%80.8), derslere ilişkin kaynak kitap, makale gibi materyalleri braille ya da büyük puntolu yazı formatında öğrenciye sunmada (\%97.3), öğrenci ihtiyacına uygun üniversitelerin ilgili birimleri tarafından sunulan yardımcı materyallere (ses kayıt cihazı, braille tablet gibi) ulaşmak konusunda (\%86.1), araştırma ödevi vermede (\%71.3), sınav sorularını hazırlamada (\%86.9) ve sinav 
kâğıtlarını görme yetersizliği olan öğrenci için uygun hale getirmede (\%87.8) güçlük yaşadıkları görülmektedir.

\section{Tablo 2. Ankette Yer Alan Maddelerin Frekans ve Yüzdelik Değerleri}

\begin{tabular}{|c|c|c|c|c|}
\hline \multirow{2}{*}{ Ankette Yer Alan Maddeler } & \multicolumn{2}{|c|}{ Evet } & \multicolumn{2}{|c|}{ Hayır } \\
\hline & $\mathrm{f}$ & $\%$ & $\mathrm{f}$ & $\%$ \\
\hline $\begin{array}{l}\text { 1. Görme yetersizliği olan öğrencinin sınıf içinde hareket etmesi gerek- } \\
\text { tiğinde onun bağımsız bir şekilde hareket etmesini desteklemede güçlük } \\
\text { yaşıyorum. }\end{array}$ & 49 & 42.6 & 66 & 57.4 \\
\hline $\begin{array}{l}\text { 2. Görme yetersizliği olan öğrencilerin bulunduğu sınıflarda dersin içeriğini } \\
\text { ve işleyişini anlatırken güçlük yaşıyorum. }\end{array}$ & 29 & 25.2 & 86 & 74.8 \\
\hline $\begin{array}{l}\text { 3. Ders izlencesini görme yetersizliği olan öğrenci için düzenlerken güçlük } \\
\text { yaşıorum. }\end{array}$ & 87 & 75.6 & 28 & 24.4 \\
\hline $\begin{array}{l}\text { 4. Görme yetersizliği olan öğrencilerin bulunduğu sınıflarda sözlü olarak } \\
\text { ders sunumu yaptığım durumlarda güçlük yaşıyorum. }\end{array}$ & 16 & 13.9 & 99 & 86.1 \\
\hline $\begin{array}{l}\text { 5. Görme yetersizliği olan öğrencinin de bulunduğu bölümlerde farklı } \\
\text { mekânlarda ders yapmam gerektiğinde (laboratuvar, bilgisayar salonu vb) } \\
\text { güçlük yaşıyorum. }\end{array}$ & 44 & 38.2 & 71 & 61.8 \\
\hline $\begin{array}{l}\text { 6. Görme yetersizliği olan öğrencilerin bulunduğu sınıflarda görsel içeriğin } \\
\text { (matematik, fen, sosyal bilimlerle ilgili dersler) yoğun olduğu dersleri an- } \\
\text { latırken güçlük yaşıyorum. }\end{array}$ & 101 & 87.8 & 14 & 12.2 \\
\hline $\begin{array}{l}\text { 7. Görme yetersizliği olan öğrencilerin bulunduğu sınıflarda akıllı tahta } \\
\text { kullanmam gerektiğinde güçlük yaşıyorum. }\end{array}$ & 89 & 77.3 & 26 & 22.7 \\
\hline $\begin{array}{l}\text { 8. PowerPoint sunumu, videolar, beher, cetvel gibi ders materyallerini } \\
\text { görme yetersizliği olan öğrencim için uyarlamam/düzenlemem gerek- } \\
\text { tiğinde güçlük yaşıyorum. }\end{array}$ & 93 & 80.8 & 22 & 19.2 \\
\hline $\begin{array}{l}\text { 9. Derslere ilişkin kaynak kitap, makale gibi materyalleri braille ya da büyük } \\
\text { puntolu yazı formatında öğrenciye vermem gerektiğinde güçlük } \\
\text { yaşıyorum. }\end{array}$ & 112 & 97.3 & 3 & 2.7 \\
\hline $\begin{array}{l}\text { 10. Görme yetersizliği olan öğrenci ihtiyacına uygun üniversitelerin ilgili bi- } \\
\text { rimleri tarafından sunulan yardımcı materyallere (ses kayıt cihazı, braille } \\
\text { tablet gibi) ulaşmak konusunda güçlük yaşıyorum. }\end{array}$ & 99 & 86.1 & 16 & 13.9 \\
\hline $\begin{array}{l}\text { 11. Görme yetersizliği olan öğrencilerin bulunduğu sınıflarda araştırma } \\
\text { ödevi verirken güçlük yaşıyorum. }\end{array}$ & 82 & 71.3 & 33 & 28.7 \\
\hline $\begin{array}{l}\text { 12. Görme yetersizliği olan öğrencilerin de bulunduğu sınıflarda sınav sor- } \\
\text { ularını hazırlarken güçlük yaşıyorum. }\end{array}$ & 100 & 86.9 & 15 & 13.1 \\
\hline $\begin{array}{l}\text { 13. Sınav kâğıtlarını görme yetersizliği olan öğrenci için uygun hale } \\
\text { getirirken güçlük yaşıyorum. }\end{array}$ & 101 & 87.8 & 14 & 12.2 \\
\hline $\begin{array}{l}\text { 14. Sınavlarda göre yetersizliği olan öğrencilere sınav sorularını okuyacak } \\
\text { ve yanıtlarını yazacak gören okuyucu-yazıcı desteği sağlarken güçlük } \\
\text { yaşıyorum. }\end{array}$ & 78 & 67.8 & 37 & 32.2 \\
\hline $\begin{array}{l}\text { 15. Görme yetersizliği olan öğrencilerin bulunduğu sınıflarda sınavları } \\
\text { gerçekleştirirken güçlük yaşıyorum. }\end{array}$ & 65 & 56.5 & 50 & 43.5 \\
\hline $\begin{array}{l}\text { 16. Görme yetersizliği olan öğrencilere sınavlarda ek süre vermem gerek- } \\
\text { tiğinde güçlük yaşıorum. }\end{array}$ & 40 & 34.7 & 75 & 65.3 \\
\hline $\begin{array}{l}\text { 17. Görme yetersizliği olan öğrencilere ait sınav evraklarını/kağıtlarını } \\
\text { okurken güçlük yaşıyorum. }\end{array}$ & 33 & 28.6 & 85 & 73.4 \\
\hline
\end{tabular}

Karşılaşılan bu güçlükleri; sinavlarda göre yetersizliği olan öğrencilere sınav sorularını okuyacak ve yanıtlarını yazacak gören okuyucu-yazıcı 
desteği sağlama (\%67.8), sinavları gerçekleştirme (\%56.5), öğrencinin sınıf içinde hareket etmesi gerektiğinde onun bağımsız bir şekilde hareket etmesini destekleme (\%42.6) ve farklı mekanlarda ders yapma (\%38.2) takip etmektedir.

Tablo 2 incelendiğinde katılımcıların en az güçlük yaşadığı durumların ise sözlü olarak ders sunumu yapma (\%13.9), dersin içeriğini ve işleyişini anlatma (\%25.2), sınav evraklarını/kağıtlarını okuma (\%28.6) ve öğrencilere sinavlarda ek süre verme (\%34.782) olduğu görülmektedir.

\section{Tartışma ve Sonuç}

Görme yetersizliği olan bireylerin eğitime erişilebilirliğini sağlamada en büyük paydaşlardan biri olan akademisyenlerin karşılaştıkları güçlüklerin belirlenmesi amaçlayan bu çalışmada çeşitli sonuçlara ulaşılmıştır. Örneğin, çalışmaya katılan akademisyenlerin en fazla görme yetersizliği olan bireylere kitap, makale gibi kaynak materyalleri verme konusunda güçlük yaşadıkları belirlenmiş $(\mathrm{n}=112)$. Ayrıca çok sayıda akademisyen ise görsel içerikli dersleri anlatırken $(\mathrm{n}=101)$, sınav sorularını hazırlarken ( $n=100)$, sınav kâğıtlarını uygun hale getirirken $(n=101)$, üniversitenin sağladığı imkânlara ulaşırken $(n=99)$, ödev verirken $(n=82)$, sinavları yaparken $(\mathrm{n}=65)$, sinavlarda okuyucu-yazıcı desteği alırken $(\mathrm{n}=78)$, akıllı tahta kullanırken $(\mathrm{n}=89)$, görsel ders araçlarını uyarlarken $(n=93)$ ve ders izlencesini düzenlerken güçlük yaşamaktadır. Akademisyenlerin nispeten daha az güçlük yaşadıkları konular ise şu şekilde sıralanabilir: Bağımsız hareket etmeyi destekleme $(n=49)$, farklı mekanlarda ders yapma $(n=44)$, ek süre verme $(n=40)$ ve sınav evraklarını okuma $(n=33)$. Bununla birlikte, akademisyenlerin en az güçlük yaşadıkları konu sözlü ders sunumu yapmadır $(\mathrm{n}=16)$. Benzer şekilde ders içeriğinin ve işleyişin anlatılması konusunda güçlük yaşadığını belirten akademisyenlerin sayısı da daha azdır ( $\mathrm{n}=29)$. Elde edilen sonuçlara göre, görme yetersizliği olan bireylerle çalışan akademisyenlerin genellikle güçlük yaşadıkları söylenebilir. Söz konusu güçlükler özellikle bazı konularda daha belirgin iken bazı konular da daha az görülmektedir. Alanyazındaki bazı araştırmalarda da benzer bulgulara rastlamak mümkündür. Örneğin; alanyazında ulaşılan sınırlı araştırmaların birinde görme yetersizliği olan bireylerin sınavlarda yardım istemesi, ders sırasında görme yetersizliği 
olan bireyin unutulması ve sorulardan değişiklik yapılması öğretim elemanları tarafından bir sorun olarak dile getirilmiştir (Kamış ve Demir, 2018). Diğer araştırmalarda ise öğretmenlerin yeterli donanıma sahip olmaması, görme yetersizliği olan bireylerin öğrenmeleri hakkında bilgi sahibi olunmaması gibi konularda güçlükler öne sürülmüştür (Şendurur, 2016; Uğurlu ve Çobanoğlu-Aktan, 2016). Dolayısıyla elde edilen sonuçlar ile alanyazındaki bilgiler arasında bir benzerlik olduğu söylenebilir. Ancak bu konuda daha fazla araştırmanın yapılmasına olan ihtiyaç aşikardır.

Görme yetersizliği olan bireyler için sinavların canlı bir okuyucu tarafından sesli olarak okunması, sınav sorularının braille ya da büyük punto şeklinde hazırlanması sınavların uygulanması ile ilgili; yanıtların sesli olarak dikte ettirilmesi, büyütülmüş cevap kağıdına işaretlenmesi veya çeşitli yardımcı teknolojiler aracılığıyla yazılması ise yanıtların alınması ile ilgili önemli düzenlemeler olarak ifade edilmektedir (Allman, 2009; Bolt and Thurlow, 2004; Douglas ve diğ., 2009). Ancak çalışmadan elde edilen bulgular kategorize edildiğinde; görme yetersizliği olan bireylerle çalışan akademisyenlerin sınav, değerlendirme veya ödevlendirme konularında güçlük yaşadıkları görülmektedir. Bu sorunlar ise soruları hazırlama, ödevlendirme (araştırma ödevi verme), okuyucu-yazıcı desteği, ek süre ve sınavı uygulama olarak karşımıza çıkmaktadır. Bu konuda üniversiteler tarafından hazırlanan Engelli Öğrenciler İçin Sınav Uygulamaları Yönergeleri incelendiğinde; sınavlarda ek süre vermek, gören okuyucu ve yazıcı sağlamak, sınavlarda bilgisayar kullanımına ve büyüteç kullanımına izin vermek, görsel içerikli soruların yerine aynı bilgi ve beceriyi ölçebilecek sözel ifadeler içeren sorular hazırlamak, öğrencinin talep etmesi durumunda braille formatta sınav kağıdı sunmak gibi uygulamaların yer aldığı görülmektedir. Ancak söz konusu yönergelerde yer alan bu hususların gerçekleştirilmesi konusunda akademisyenlere gerekli ve yeterli desteğin sağlanmadığı düşünülmektedir. Özellikle sınav dönemlerinde fakülte veya üniversite bazında neredeyse tüm öğrencilerin sınavlarının olduğu düşünüldüğünde, alternatif okuyucular ya da yazıcılar yoksa eğer akademisyenlerin bu konuda zorlanmaları şaşırtıcı değildir. Tabi bu durum aynı zamanda sınavların uygulanmasını da zorlaştırabilecek bir faktör olarak görülebilir. Örneğin, okuyucu ya da yazıcı ile sınav olan bireyler için ayrı bir ortam gerekmektedir (Doğuş ve diğg., 2020). Dolayısı ile sınavların uygulamasında güçlükle karşılaşılmasının 
bir diğer nedeni ortamsal özellikler olarak ifade edilebilir. Görme yetersizliği olan öğrenciler genelde gören okuyucu ve yazıcı ile sınav olmaktadırlar. Ancak buna ek olarak, görme yetersizliği olan bireyler için farklı sınav uygulamaları da gerçekleştirilebilir. Bu uygulamalara braille daktilo, tablet veya bilgisayar gibi yardımcı araçların kullanımı örnek verilebilir. Alanyazında bazı yapılan bazı çalışmalarda görme yetersizliği olan öğrencilerin braille daktilo ya da braille tablet ile sinava girmek istedikleri (Doğuş ve diğg., 2020) ve bu şekilde yapılan sınavlarda daha başarılı oldukları (Erin, Hong, Schoch and Kuo, 2006) görülmektedir. Öte yandan yapılan bir çalışmada öğrencilerin gören okuyucu ve yazıcıyla sınav olmayı tercih ettikleri de belirlenmiştir (Yalçın, 2015). Öğrencilerin bu uygulamayı tercih etmelerinin nedenleri arasında, braille yazma sürecinin uzun zaman alması, ek süreye ihtiyaç duymaları ve sınavları okuyan eğitmenlerin braille yazıyı bilmemeleri gibi pek çok neden sıralanabilir. Üniversitelerin mevcut imkanları veya görme yetersizliği olan bireylerin sahip oldukları imkanlar yardımcı araç kullanımını sınırlandırabilecek faktörler olarak düşünülmektedir. Görme yetersizliği olan bireylerle çalışan akademisyenlerin güçlük yaşadığı diğer bir konu ise sınav kâğıtlarını uygun hale getirme ve sınav sorularını hazırlamadır. Görme yetersizliği olan bireyler için özellikle braille soru hazırlayabilmek için akademisyenlerin braille yazıyı biliyor ve kullanmıyor olması veya üniversitelerin bir biriminde braille baskı yapan (braille yazıcı) araçların bulunması gerekir. Bunların olmaması veya bulunmamasının bir sonucu olarak akademisyenlerin güçlük yaşadıkları düşünülebilir.

Görme yetersizliği olan bireylerin gören akranları ile eşit eğitim imkanlarından yararlanabilmeleri için birtakım düzenlemelere ihtiyaç vardır. Örneğin, bu bireylerin eğitiminde özel tasarlanmış araçların ve uyarlanan öğretim yöntemlerinin kullanılması gerekebilmektedir (Kamış ve Demir, 2018). Bununla birlikte, görsel materyallerin kullanımına ek olarak özellikle dokunsal ve işitsel materyallere de gereksinim duyarlar (Yalçın ve Kamalı Arslantaş, 2020). Bu yönüyle çalışmadan elde edilen bulgulara bakıldığında; akademisyenlerin güçlük yaşadıkları konuların kitap, makale gibi kaynak materyallerin verilememesi, görsel içeriğin aktarılamaması, yardımcı materyallere ulaşamama, akıllı tahta kullanamama ve görsel ders materyalleri uyarlayamama olduğu görülmektedir. Çalışmanın 
bu bulgusu, şaşırtıcı olmamakla birlikte son yıllarda teknolojik gelişmelerin sunduğu pek çok kolaylığın sınıf ortamlarında kullanılmadığına işaret etmektedir. Diğer bir ifadeyle görme yetersizliği olan bireylerin gereksinimlerine ilişkin düzenlemelerin yeterince gerçekleştirilemediği sonucuna gidilebilir. Görme yetersizliği olan bireyler için düzenlenmiş ve özel olarak geliştirilmiş pek çok yardımcı teknolojik araç-gereç kullanılarak bu bireylerin derslere erişimi sağlanabilmektedir. Örneğin; ekran okuma programları, not tutmaya yarayan NoteTaker, braille hazırlanmış ders materyalleri bu uygulamalardan bazılarıdır (Aslan, 2016, s.60; Çakmak, 2018, s.12; Landau, Russell, Gourgey, Erin and Cowan, 2003; Thurlow, Johnstone, Timmons and Altman, 2009). Söz konusu bu cihazların ya da programların sağlanmasının birincil olarak akademisyenlerin sorumluluğunda olmadığını söylemek yanlış olmayacaktır. Bu konuda özellikle üniversitelerin Engelli Öğrenci Birimleri tarafından destek alınabilir. Söz konusu destek materyal veya araç-gereç temini açısından olabilir. Örnek vermek gerekirse, ses kayıt cihazı gibi bir yardımcı materyal bu birimler tarafından temin edilebilir, öğrenci okuldan ayrıldığında bu cihazın üniversiteye iade etmesi sağlanabilir. Bununla birlikte görme yetersizliği olan öğrencilerle çalışan akademisyenlerin öğrencilerini bu tür cihazları kullanmaya teşvik etmeleri etkili ve verimli sonuçlar doğurabilir. Görme yetersizliği olan öğrencilerle çalışan eğitimcilere ders öncesi, sırası veya sonrasında yapılması gereken birçok görev düşmektedir (Güray, 2017). Ancak şu da belirtilmelidir ki; çoğu akademisyen çalışma yaşamları boyunca yetersizliği olan sınırlı sayıda birey ile karşılaşmakta ya da hiç karşılaşmamaktadır. Bu nedenle söz konusu bireylerin ihtiyaçlarının ne olduğu konusunda sınırlı bilgiye sahip olmakta ve hangi düzenlemeleri nasıl yapacakları konusunda desteğe ihtiyaç duyabilmektedir. Bu yönüyle de, öğretim elemanlarının görme yetersizliği olan bireylerle çalışırken çeşitli sorunlar yaşamaları beklenen bir durum olarak görülebilir.

Alanyazındaki bazı araştırmalarda görme yetersizliği olan bireylerin özellikle görsel materyallere erişim konusunda problem yaşadıkları ifade edilmektedir (Menzi-Cetin, Alemdağ, Tüzün ve Yıldız, 2017; Okur ve Demir, 2019; Mokiwa and Phasha, 2012). Yapılan bu çalışmada da akademisyenlerin bir bölümü görsel içerikleri anlatma, sunma veya uyarlama konularında güçlük yaşadıklarını dile getirmişlerdir. Akademisyenlerin 
güçlük yaşadığı bu durumlar görme yetersizliği olan öğrencilerin derslere erişimi için son derece önemli durumlar olarak ifade edilebilir. Görme yetersizliği olan öğrenciler için ders sırasında veya öncesinde yapılacak bazı uyarlamalar ile bu güçlüklerin üstesinden gelinebilir. Burada şunlar yapılabilir; söz konusu içerik braille formatında yazdırabilir, büyük puntolu olacak şekilde bastırılabilir veya elektronik ortamda sunabilir. Bazı durumlarda görme yetersizliği bireylerin akranlarından yardım alınabilir ve sınıftaki bir arkadaşının yardımcı olması istenebilir. Ders içerisinde ise özellikle görsel içerik sunumunda içeriğin betimlenmesi görme yetersizliği olan bireyler için önemli bir uygulamadır. Bu sayede içerik hakkında fikir sahibi olabilirler. Ayrıca bir materyal kullanılıyorsa öğrencinin, bu araç-gereçler veya materyallere dokunarak tanımasını sağlayabilir. Ardından materyal ve materyale ilişkin özelliklerini anlatabilir.

Çalışmadan elde edilen bulgular, görme yetersizliği ile çalışan akademisyenlerin bilgi ve deneyimlerini arttıracak eğitimler sunulması gerektiğine dair önemli ipuçları sağlamıştır. Bununla birlikte üniversitelerin Engelli Öğrenci Birimleri'nin daha aktif olmaları gerektiği söylenebilir. Bu aktiflik süreci ise sadece öğrenci boyutundan ziyade, yetersizliği olan bireylerle çalışan akademisyenleri de içermelidir. Çünkü bu birimlerin sağlayacağ1 destek büyük önem arz etmektedir. Ayrıca üniversitelere görme yetersizliği olan öğrencilerin eğitim öğretim yaşamlarını ve bilgiye erişimlerini kolaylaştıracak materyallerin ve teknolojik araç gereçlerin sağlanması önerilmektedir. Bu sayede görme yetersizliği olan bireylerin eğitim-öğretim faaliyetlerine eşit oranda katılımı sağlanabilir. Bunu yapabilmek adına üniversiteler tarafından söz konusu yardımcı ekipmanların edinimi için YÖK'ün ek bütçe sunmasının gerekli olduğu düşünülmektedir.

Bununla birlikte görme yetersizliği olan üniversite öğrencilerinin dersleri takip etmede, ödev hazırlamada, sınavlara hazırlanmada ve sınav esnasında karşılaştıkları güçlükleri ortaya koyacak çalışmaların yapılması da gerekmektedir. Bu şekilde YÖK tarafından akademisyenlerin ve öğrencilerin karşılaştıkları güçlükleri ortadan kaldıracak tedbirler alınabilir. Öte yandan farklı fakülte ve bölümlerde bu tür çalışmalar gerçekleştirilerek bölümlere göre de farklı tedbirlerin alınması da alınabilir. 


\section{EXTENDED ABSTRACT}

\section{Determining the Difficulties Encountered by Academicians Teaching with Students with Visual Impairments}

Gülistan Yalçın- Cem Aslan

Aksaray University- Gazi University

Most academicians have limited, or no encounters with individuals with disabilities throughout their working lives. For this reason, the individuals in question have limited knowledge of what their needs are and may need support on how to make arrangements. In this respect, it is thought that instructors may experience various problems while working with individuals with visual impairment, in other words, while conducting their lessons. Educators who will work with these individuals have many duties before, during, or after the lecture. This study will provide an essential basis for determining the problems experienced by the instructors working with individuals with visual impairment and for suggesting solutions to these problems. Therefore, it is expected to contribute to the knowledge unit in the literature. It is also considered essential to describe the current situation to improve the services provided to individuals with visual impairment. This context aimed to determine the difficulties academics face, who are among the most prominent stakeholders, in ensuring the accessibility of individuals with visual impairments to education.

This study aimed to determine the difficulties encountered by academicians teaching with students with visual impairments. The study participants, which was designed according to the descriptive research model, consisted of 115 academicians who attended classes with students with visual impairments. Descriptive research is "the research method to be applied when searching for answers to research problems by analyzing data obtained from a large number of subjects or objects in a certain time period." In addition, 67 (58.2\%) of the participants are female, 48 (41.7\%) are male, and the participants work in different departments of the universities. On the other hand, $30(26.0 \%)$ of the participants were special 
education teachers, $20(17.3 \%)$ were music teachers, $18(15.6 \%)$ were history teachers, $16(13.9 \%)$ were science teachers, $13(11.3 \%)$ were teachers work in preschool teaching, $10(8.6 \%)$ of them work in economics and business administration and $8(6.9 \%)$ in education measurement and evaluation departments.

The data collection process of the research was carried out electronically. The data were collected through a questionnaire developed by researchers. The questionnaire consists of two parts. In the first part, there is personal information (gender, department). There are 17 closed-ended questions in the second part and "Yes" and "No" boxes to mark the answers to the questions. They sent a questionnaire to 178 academicians; 115 filled out the questionnaire and returned it to the researchers. Other academics did not give any feedback on the questionnaire. The researchers deemed the number of questionnaires obtained was sufficient, and they started the data analysis process. The data of the study were analyzed using frequency and percentage techniques. In this context, a table was created regarding the items in the questionnaire, and the frequencies and percentages of the answers (yes, no) were given.

As a result, it was determined that the academicians participating in the study had the most difficulty giving source materials such as books and articles. In addition, the researchers observed that they faced challenges in lecturing with visual content, preparing or adaptation questions, accessing the opportunities provided by the university, assignments, exams, and adapting the course materials. However, it was determined that they had less difficulty supporting the independent movement, teaching in different places, giving additional time, reading exam documents, giving oral lessons, explaining the course content and procedure.

The researchers discussed academicians' opinions with the relevant literature and provided suggestions for further studies and applications. According to the results obtained, it can say that academicians working with individuals with visual impairment generally have difficulties. While these difficulties are more evident in some subjects, they are seen less in some topics. It is possible to encounter similar findings in some studies in the literature. The conclusions of the study provided important clues. It can say that the Disabled Student Units of the universities should be more active. This activity process should include academicians working with 
individuals with disabilities rather than just the student dimension because the support of these units is of great importance. In addition, it is recommended that universities provide materials and technological tools that will facilitate the education life and access to information of students with visual impairment. In this way, it can ensure that individuals with visual impairments participate equally in educational activities. In addition, it is necessary to carry out studies that will reveal the difficulties faced by university students with visual impairments in following the lessons, preparing homework, preparing for exams, and during exams. In this way, measures can be taken by the Council of Higher Education to eliminate the difficulties faced by academicians and students. On the other hand, such studies can be carried out in different faculties and departments, and they can take additional measures according to the departments.

\section{Kaynakça / References}

Allman, C. B. (2009). Test access: Making tests accessible for students with visual impairments. http://www.aph.org/files/tests/access2/access2.pdf sayfasindan erişilmiştir. Erişim tarihi: 01.04.2021

Arseven, A. D. (1994). Alan araştırma yöntemi ilkeler teknikler örnekler. Ankara: Gül.

Aslan, C. (2016). Görme engelliler için yardımc teknolojiler. S. Çakmak (Ed.), Özel eğitimde yardıma teknolojiler içinde (s.56-92). Ankara: Vize.

Bolt, S. E. and Thurlow, M. L. (2004). Five of the most frequently allowed testing accommodations in state policy: Synthesis of research. Remedial and Special Education, 25(3), 141-152.

Çakmak, S. (2018). Yardıma teknoloji, tarihçe ve genel kavramlar. S. Çakmak (Ed.), Özel eğitim ve yardımcı teknolojiler. içinde (s.6-17). Ankara: Vize.

Doğuş, M., Aslan, C. ve Cakmak, S. (2020). Görme engelli bireylerin merkezi sinav düzenlemelerine ilişkin görüşleri. Eğitim ve Toplum Araştırmalan Dergisi, 7(1), 219-247.

Douglas, G., McCall, S., Pavey, S. and Nisbet, P. (2009). Summary report on international systems of exam access for visually impaired pupils. https://wwww.rnib.org.uk/.../international_exams_survey.doc sayfasindan erişilmiştir. Erişim tarihi: 11.03.2021 
Erin, J. N., Hong, S., Schoch, C. and Kuo, Y. (2006). Relationships among testing medium, test performance, and testing time of high school students who are visually impaired. Journal of Visual Impairment \& Blindness, 100(9), 523-532.

Güray, Ş. (2017). Yüksek lisans eğitiminde hizmet kalitesi bağlammnda görme engelli bir öğrencinin öğrenme yaşantılarının incelenmesi. Başkent University Journal of Education, 1(2), 66-73.

Kamış, Ö. ve Demir, E. (2018). Görme Yetersizliği olan lisans öğrencilerinin sınıf içi ölçme-değerlendirme süreçlerinin incelenmesi. Ozel Egitim Dergisi, 19(3), 423.

Kim, J. S. (2012). The effect of" read-aloud" as a test accommodation for students with visual impairments in South Korea. Journal of Visual Impairment \& Blindness, 106(6), 356-361.

Kreuzer, D. T. (2007). An analysis of writing practices in 4th-and 5th-grade students with visual impairments. University of California, Berkeley with San Francisco State University.

Landau, S., Russell, M., Gourgey, K., Erin, J. N. and Cowan, J. (2003). Use of the talking tactile tablet in mathematics testing. Journal of Visual Impairment $\mathcal{E}$ Blindness, 97(2), 85-96.

Menzi-Çetin, N., Alemdağ, E., Tüzün, H. ve Yıldız, M. (2017). Evaluation of a university website's usability for visually impaired students. Universal Access in the Information Society, 16(1), 151-160.

Mokiwa, S. A. and Phasha, T. N. (2012). Using ICT at an open distance learning (ODL) institution in South Africa: The learning experiences of students with visual impairments. Africa Education Review, 9(sup1), 136-151.

Okur, M. R. ve Demir, M. (2019). Görme engelli öğrenenlerin eğitim yaşantısında karşılaştıkları sorunların belirlenmesi, açık ve uzaktan öğrenme alanı için çözüm yolları geliştirilmesi. $A U A d, 5(2), 49-62$.

Özel Eğitim Hizmetleri Yönetmeliği [Turkish Special Education Services Regulation]. (2018). Resmi Gazete (Document No: 30471). http://www.resmigazete.gov.tr/eskiler/2018/07/20180707-8.htm Erişim tarihi: 06.05.2021

Smith, D. W. and Amato, S. (2012). Synthesis of available accommodations for students with visual impairments on standardized assessments. Journal of Visual Impairment \& Blindness, 106(5), 299-304.

Stone, E., Cook, L., Laitusis, C. C. and Cline, F. (2010). Using differential item functioning to investigate the impact of testing accommodations on an English- 
language arts assessment for students who are blind or visually impaired. Applied Measurement in Education, 23(2), 132-152.

Şendurur, Y. (2016). Görme engelli müziköğretmenlerinin görme engelli öğrencilerin çalg1 eğitimi dersi sürecine ilişkin görüşleri. Abant İzzet Baysal Üniversitesi Eğitim Fakültesi Dergisi, 16, 2477-2488.

Thurlow, M., Johnstone, C., Timmons, J. and Altman, J. (2009). Survey of teachers of studenst with visual impairmenst: Students served and their access state assessment of reading. https://nceo.umn.edu/docs/OnlinePubs/TARA/TARAteacherSurvey.pdf sayfasından erişilmiştir. Erişim tarihi: 04.04 .2021

Tuncer, T. (2014). Görme yetersizliği olan çocuklar. Vuran, S. (Ed.), Özel eğitim içinde (s.297-328). Ankara: Maya.

Uğurlu, S. and Çobanoğlu-Aktan, D. (2016). Görme engelli öğrencilere istatistik öğretiminde karşllaşılan sorunlar [Problems in statistical teaching of visually impaired students]. Uluslararası Çağdaş Eğitim Araştırmalan Kongresinde sunulan bildiri, Muğla.

Yalçın, G. (2015). Ortaöğretimde birlikte eğitim ortamlarnna devam eden görme yetersizliğinden etkilenmiş̧ ögrencilerin tamamlayıcı becerileri kullanma düzeyleri ve tercihlerine yönelik görüşleri. Yayınlanmamış yüksek lisans tezi. Gazi Üniversitesi, Eğitim Bilimleri Enstitüsü, Ankara.

Yalçı, G. ve Kamalı Arslantaş, T. (2020). Mentoring inservice teachers to support their inclusive science teaching practices for students with visual impairment. International Journal of Contemporary Educational Research, 7(2), 112-131. https://doi.org/10.33200/ijcer.741436.

Yükseköğretim Kurumları Engelliler Danışma ve Koordinasyon Yönetmeliği. (2006).https://www.mevzuat.gov.tr/mevzuat?MevzuatNo=14214EMevzuatTur $=$ FEMevzuatTertip=5 sayfasından erişilmiştir. Erişim tarihi: 19.03.2021

\section{Kaynakça Bilgisi/Citation Information}

Yalçın, G. ve Aslan, C. (2021). Görme yetersizliği olan öğrencilerin derslerini yürüten akademisyenlerin karşılaştıkları güçlüklerin belirlenmesi. OPUS- Uluslararası Toplum Araştırmaları Dergisi, 18(41), 3260-3279. DOI: 10.26466/opus.916007. 